\title{
Opinion 56
}

\section{Rejection of the Species Name Peptococcus anaerobius (Hamm) Douglas 1957}

\author{
Judicial Commission of the International Committee on Systematic Bacteriology
}

The species name Peptococcus anaerobius (Hamm) Douglas 1957 has been rejected by the Judicial Commission of the International Committee on Systematic Bacteriology.

West and Holdeman (6) requested an opinion placing the name Peptococcus anaerobius (Hamm) Douglas 1957 (1) on the list of nomina rejicienda. They presented evidence that the original description (2) was too brief to permit conclusive diagnosis and was based on strains, none of which survive, but which represent two or possibly three different species. This qualifies the name for rejection as a nomen dubium under Rule 56a of the Bacteriological Code (4). Furthermore, West and Holdeman suggest that the name Peptococcus anaerobius could easily be confused with Peptostreptococcus anaerobius, and the implications of such confusion would be serious since strains bearing both names have clinical significance. This permits consideration of the name as a nomen perplexum under Rule 56 a as well. Peptococcus anaerobius was omitted from the Approved Lists of Bacterial Names (5), but the Judicial Commission, voting while the name still had standing (3), i.e., before publication of the Approved Lists, awarded the Opinion that the name be placed on the list of nomina rejicienda, thus making it unavailable for future use.
Opinion 56. The species name Peptococcus anaerobius (Hamm) Douglas 1957 is placed on the list of nomina rejicienda as a nomen dubium and a nomen perplexum because it is a source of confusion.

\section{LITERATURE CITED}

1. Douglas, H. C. 1957. Genus VI. Peptococcus Kluyver and van Niel, 1936, p. 474-480. In R. S. Breed, E. G. D. Murray, and N. T. Smith (ed.), Bergey's manual of determinative bacteriology, 7 th ed. The Williams \& Wilkins Co., Baltimore.

2. Hamm, A. 1912. Die puerperal Wundinfektion. Julius Springer, Berlin.

3. Judicial Commission of the International Committee on Systematic Bacteriology. 1979. Minutes of the meeting, 3 September 1978. Int. J. Syst. Bacteriol. 29:267-269.

4. Lapage, S. P., P. H. A. Sneath, E. F. Lessel, V. B. D. Skerman, H. P. R. Seeliger, and W. A. Clark (ed.). 1975. International code of nomenclature of bacteria. American Society for Microbiology, Washington, D.C.

5. Skerman, V. B. D., V. McGowan, and P. H. A. Sneath (ed.). 1980. Approved lists of bacterial names. Int. J. Syst. Bacteriol. 30:225-420.

6. West, S. E. H., and L. V. Holdeman. 1973. Placement of the name Peptococcus anaerobius (Hamm) Douglas on the list of Nomina rejicienda. Request for an opinion. Int. J. Syst. Bacteriol. 23:283-289. 